\title{
EFFECTS OF GRAFTING WITH ACRYLIC ACID ON WETTING OF POLYESTER FABRIC AND ITS SOIL RELEASE PROPERTY
}

\author{
By Tokuzo Kawase, Yoshiko Morimoto, Tomiko Fujii and Motoi Minagawa \\ (Faculty of Science of Living, Osaka City University, \\ 3-3.138 Sugimoto, Sumiyoshiku, Osaka 558, Japan)
}

\begin{abstract}
Based on the surface characterization (FT-IR) of acrylic acid grafted polyester fabric (PET) after treated with aqueous $\mathrm{Na}_{2} \mathrm{CO}_{3}$, both the variation of wettability of PET to water and the improvement of soil release properties were highly correlated to the amount of introduced $\mathrm{COOH}$ groups on fiber surface (SGD). The capillary spreading measurements were employed to compare the wettability of fabrics and surface treatments. The values of $A_{1}$, the area at the time 1 min, and $n$, the slope of spreading of water during phase Il. of grafted PET increased and decreased with increasing in the grafting degree or SGD. respectively. It was explained in terms of surface modification to more hydrophilic and a smaller advancing contact angle of the fiber to water $(\theta)$.
\end{abstract}

\section{INTRODUCTION}

Wetting of textiles with water is of fundamental im. portance in detergency, dyeing and finishing, and is therefore of considerable practical interest. Especially. the detergency of oily soil is closely correlating to the wettability of the fiber surface to water.

To compare the wettability and hydrophilicity of fabrics, the contact angles of water on film substrates have been measured for convenience. But. as we reported ${ }^{1 \text { ). }}$ the wettability of film does not always agree with those of fabrics owing to their geometrical structure.

In our previous papers $2-4$, we investigated the capil. lary spreading of liquid drops in fabrics based on the Gillespie's two phase concept ${ }^{5)}$ (phase I and II) and Kissa's exponential sorption ${ }^{6)}$ during phase II, when the liquid is completely contained within the fabric and spreading along the capillaries,

$$
A=K(\gamma / \eta)^{\prime \prime} V^{m} \iota^{n}
$$

where $A$ is the area covered by the spreading liquid, $K$ the capillary sorption coefficient, $\gamma$ the surface tension, $\eta$ the viscosity, and $V$ the volume of liquid, and reported the relation between the hydrophobicity of the $\mathrm{fi}$ ber and the capillary spreading of decane $e^{3}$.

To help the removal of oily soil, the fiber surface has to be made more hydrophilic with soil release finishes. In this work, we selected the grafting of acrylic acid as a hydrophilization of PET, because it has been regarded as one of the effective chemical soil release finishing where the wettability of fabric can be varied with minimum change in the bulk properties.

Our study focuses on the relationships between the wettability of PET fiber surface, the detergency of oily soil (soil release property), the grafting degree and/or the amount of $\mathrm{COOH}$ group introduced on fiber surface. Thus, we examined the capillary spreading of water drop into acrylic acid grafted fabrics and the washing experiments using nonpolar oily soil to elucidate the effect of grafting on wettability of PET. We also characterized the surface of grafted PET fabrics by FT-IR (ATR), and determined the surface grafting degree as a new measure of grafting degree.

\section{EXPERIMENTAL}

\subsection{Materials}

The fabric was poly (ethylene terephthalate) muslin of staple fibers $\left(17.3 \mathrm{mg} / \mathrm{cm}^{2}\right.$, yarn density $23 \times 23(\mathrm{~W} \times$ F), and porosity $62.9 \%$ ). The fabric was purified as described previously ${ }^{2)}$.

The spreading liquid was distilled water colored with $0.1 \% \mathrm{Cl}$ Acid Blue 9 to aid the observation of capillary spreading.

The oily soil used in washing experiment was squalane $(2,6,10,15,19,23$-hexamethyltetracosane) which was 
purified by column chromatography on silica until the interfacial tension at oil/water interface became constant $(43.1 \mathrm{mN} / \mathrm{m})$.

\subsection{Grafting of PET with Acrylic Acid}

According to Ohguchi $e t a l^{7)}$, the polyester fabric was subjected to grafting with acrylic acid with some mod. ification. A solution of benzoyl peroxide (Wako), $0.75 \mathrm{~g}$. Prisurf-A as emulsifying agent (Dai-ichi Kogyo Seiyaku), $1.5 \mathrm{~g}$, and monochlorobenzene, $6 \mathrm{~g}$, was finely dispersed in $125 \mathrm{ml}$ of distilled water by ultrasonic apparatus. To this emulsion an aqueous solution of acry. lic acid was added, and the volume was adjusted to 750 $\mathrm{ml}$. The concentration of acrylic acid was prepared as 1 , $2,3,4,5,6,8$ and $10 \mathrm{vol} \%$. To this solution was added three sheets of fabric $\left(18.0 \times 18.0 \mathrm{~cm}^{2}\right)$, and nitrogen was passed under vibromixing for $10 \mathrm{~min}$. The solution was heated to $100^{\circ} \mathrm{C}$ and maintained for $1 \mathrm{~h}$ under nitrogen bubbling and vibromixing. Fabrics were extracted with a large amount of bolling water for $2 \mathrm{~h}$ to re. move homopolymer, and dried.

The grafting degree (graft $(\%))$ was calculated by graft $(\%)=100 \times\left(G-G_{0}\right) / G_{0}$

where $G_{0}$ and $G$ are the weights of fabrics before and af. ter grafting at the absolutely dried condition, respec. tively.

Grafting experiments were repeated more than twice for each concentration, and the grafting degree is given on the average in Fig. 1.

\subsection{Capillary Spreading of Water}

The apparatus used in the spreading studies was previously described ${ }^{4 /}$. A fabric was mounted on a wooden frame, placed in the cell along with a timer and a stan. dard area $(5.0 \mathrm{~cm}$ diameter), and left overnight under saturation with a water vapor at $25^{\circ}$. A measured amount $(0.10 \mathrm{ml})$ of water was introduced onto the fabric by a micropipette. The area of the spreading liquid, the timer, and the standard area were recorded simultaneously on a videotape. The temperature of the apparatus was main. tained at $25^{\circ} \mathrm{C}$ throughout the experiments. The spread. ing area was determined by the image analizing technique ${ }^{u}$ using the calibration curves.

One spreading measurement was done for each grafting degree $(1.5,2,3,4,6$ and $8 \%)$.

\subsection{Washing}

The fabric, which had been used in the spreading measurement, was cut out four $5 \times 10 \mathrm{~cm}^{2}$ specimens.
Each specimen was soiled by spotting $0.2 \mathrm{ml}$ benzene solution of squalane with micropipette twice. The soiled amount was $30 \mathrm{mg}$. Three of four soiled fabrics were subjected to the washing experiments as follows.

A washing solution $(45 \mathrm{ml}$ of $0.2 \%$ sodium dodecyIbenzene sulfonate) was placed in a $100 \mathrm{ml}$ flask and kept in an incubator (M-100N, Taiyo Kagaku $\mathrm{C}_{0}$ ) at $30^{\circ} \mathrm{C}$ for $10 \mathrm{~min}$. Washing was started by adding of one piece of soiled fabric and shaking for $1 \mathrm{~h}$ at 100 s.p.n. and shaking distance of $4 \mathrm{~cm}$. Washed fabric was twice rinsed with $100 \mathrm{ml}$ of distilled water at $30^{\circ} \mathrm{C}$ for $5 \mathrm{~min}$ and then dried. Residual squalane on fabric was ex. tracted by a micro Soxhlet with ethyl ether for $4 \mathrm{~h}$. After ethyl ether was evaporated, $5 \mathrm{~m}$ l of hexane solution of $n$-hexadecane (extra pure, Tokyo Kasei) $(6 \mathrm{mg} / \mathrm{ml})$ was added to the extract as internal standard. Squalane was quantitated by gas chromatography using Shimadzu GC-7A under the following conditions: column, $3 \mathrm{~mm} \times$ $1 \mathrm{~m}$ of stainless steel packed with silicon Ge SE-30 (Gaschro Kogyo Co.); carrier gas, nitrogen, $35 \mathrm{ml} / \mathrm{min}$; flow rate of hydrogen, $40 \mathrm{ml} / \mathrm{min}$; flow rate of air, 800 $\mathrm{ml} / \mathrm{min}$. VPC analyses were repeated three times for each fabric.

Removal was determined by

$$
\text { removal }(\%)=100 \times\left(W_{0}-W\right) / W_{0}
$$

where $W_{0}$ and $W$ are the amount of squalane on fabric before and after washing, respectively.

\subsection{FT-IR Measurement}

FT-IR (ATR) spectra were obtained on a Nicolet FT-IR Model 5DX spectrometer using the Ge crystal prism. Fabric samples were the same used in the capil. lary spreading measurements and washing experiments. Pieces of PET fabric were cut to the size of Ge crystal faces and pressed against the faces with a Burnes Model 300 ATR sample holder. After subjected to the normal measurement, fabrics were treated with aqueous sodium carbonate solution $\left(0.2 \%\right.$ at $25^{\circ} \mathrm{C}$ for $\left.10 \mathrm{~min}\right)$ and dried under vacuum before contact with the Ge crystal.

\section{RESULTS AND DISCUSSION}

\subsection{Grafting of PET}

For cellulosic fabrics, such as cotton and rayon, the sorption and diffusion of water into fibers greatly inilu. enced the capillary spreading ${ }^{2)}$. On the other hand, we did not observe any penetration of the water drop in nylon and polyester fabrics ${ }^{2}$. Therefore, to study the 


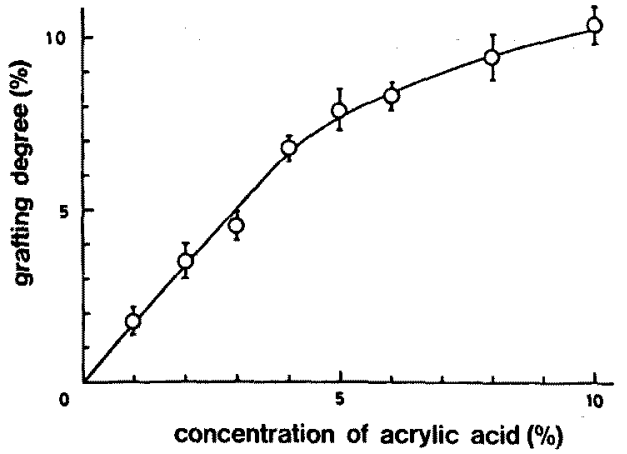

Fig. 1 Effect of the concentration of acrylic acid on the grafting degree of PET fabrics.

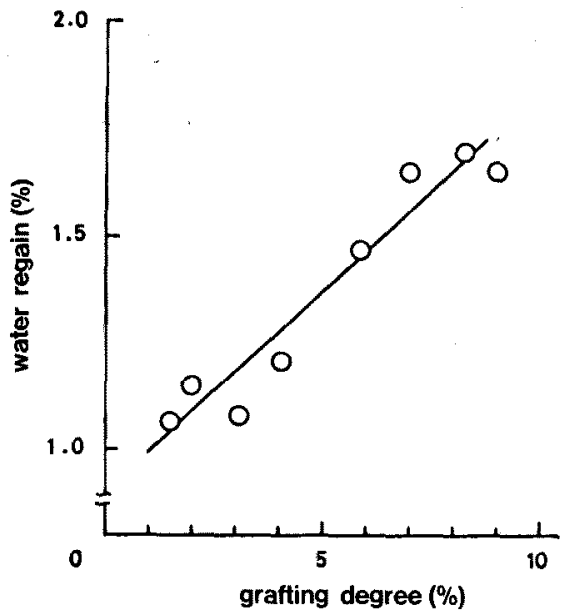

Fig. 2 Effect of grafting of acrylic acid on the water re. gain of PET fabrics $\left(25^{\circ} \mathrm{C}, 65 \% \mathrm{RH}\right)$.

wettability of fabrics to water by the capillary spreading measurements, it may be necessary that (1) the fabric substrates are impermeable to water and (2) fiber sur. faces are hydrophilic to a certain degree. To satisfy these conditions, polyester fabric was employed as substrate and grafted with acrylic acid to vary the surface free energies with minimum change in bulk properties.

In this work, though there have been reported many grafting techniques, we adapted Ohguchi's two-step grafting method ${ }^{7)}$ with some modification. As a result, the grafting degree of PET fabric increased with the concentration of acrylic acid (Fig. 1), and the water regain, which may be one of the measure of hydrophilicity, also increased almost linearly against the grafting degree similar to the Ohguchi's results ${ }^{7)}$. For example, the water regains of grafted PET fabrics used in the spreading measurement are shown in Fig. 2.

\subsection{Capillary Spreading Measurement}

The introduction of $\mathrm{COOH}$ groups onto the hydrophobic PET would exert a great influence on the static and dynamic wettability of PET. Here, we investigated the capillary spreading of water in grafted PET fabrics as the dynamic wetting test.

Though the spreading of water might slightly depend on the drop volume ${ }^{2)}$, the volume of water drop was kept constant at $0.10 \mathrm{ml}$ on the supposition that the diffusion of water into the grafted PET fibers would be negligible even if occurred. The examples of water spreading in grafted PET are shown in Fig. 3 by plotting the areas against time on a logarithmic scale. In Fig. 3, the spreading during phase $\mathrm{I}$, when some of water remains on $\mathrm{PET}$ fabric surface, was omitted because it usally terminates in a short time (less than $10 \mathrm{~s}$ ).

As can be seen in Fig. 3, though no penetration of water into ungrafted PET fabric was observed, the spread. ing of water in grafted fabrics proceeded more and more rapidly with increase in grafting degree and the slopes of the spreading were remarkably influenced by the grafting degree, but the final areas were constant. According to $\mathrm{Kissa}^{6,8)}$, the exponential equation, Eq (1), holds only for capillary sorption in the absence of the absorption and/or the diffusion of liquid into fibers or a coated film on fibers. The constant final areas would indicate that the $\mathrm{COOH}$ groups introduced on fiber surface by grafting are quite different from those of the poly (acrylic acid) film, and that the absorption or diffusion of water into fibers can be neglected as supposed. Therefore, $\mathrm{Eq}$ (1) can be reasonably expected to hold

The coefficient $K$ in $\mathrm{Eq}$ (1) is given by

$$
K=\frac{27 \pi b q_{s} \cos \theta}{8 h^{2} C_{s}^{3}}
$$

and dependent on the advancing contact angle of liquid on fibers, $(\theta)$, the permeability $\left(q_{s}\right)$ and thickness $(h)$ of the fabric, and the saturation concentration of the $\mathrm{l}$ quid in fabric $\left(C_{s}\right)^{6)}$. Kissa ${ }^{6)}$ states that, when the fibers are impermeable to the liquid, the coefficient $K$ varies with the advancing contact angle and indicates the wetta. bility of the fabrics.

As the grafted PET fibers can also be regarded as impermeable to water, $K$ would be expected to correlate with the contact angle. Besides $\theta$, however, $K$ involves many parameters which are not easy to measure. Hence. 


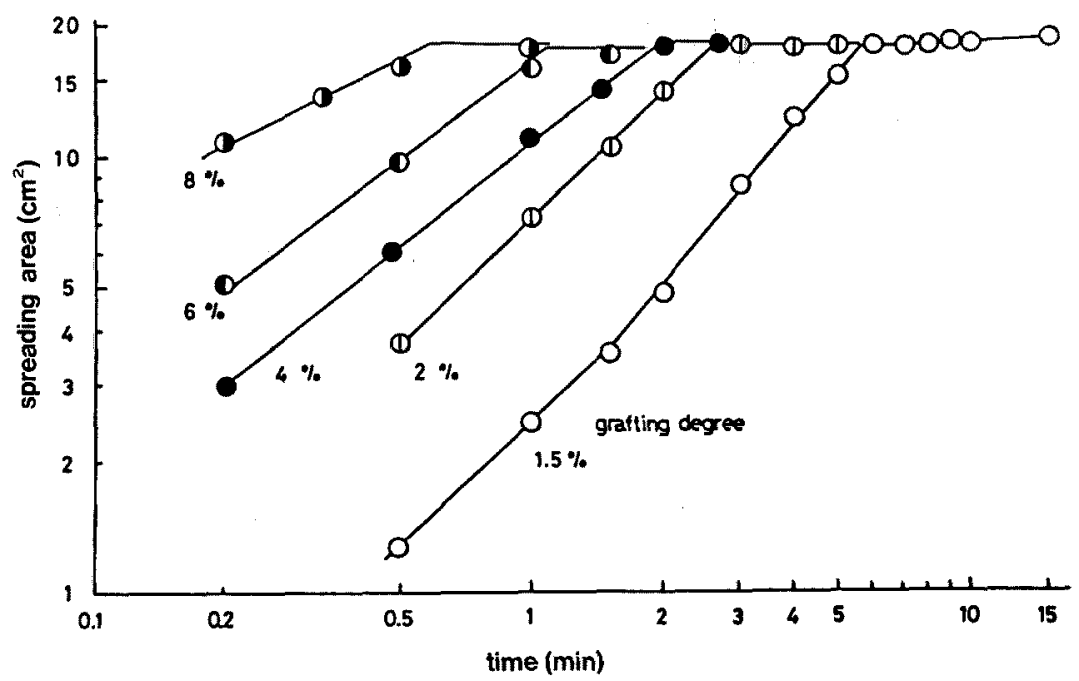

Fig. 3 Logarithmic plots of the area covered by water drop in grafted PET fabrics as a function of time. Grafting degree $(\%): 0,1.5 ;(1,2 ; 0,4 ; 0,6$; and $(8.8$.

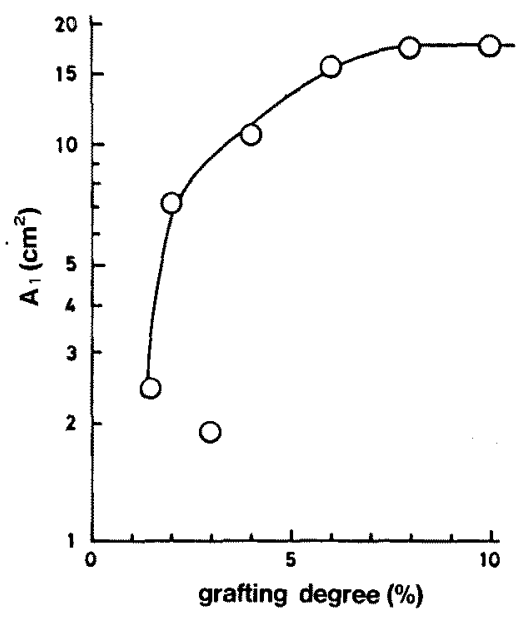

Fig. 4 Effect of grafting of acrylic acid on the capillary spreading area at $1 \mathrm{~min}\left(A_{1}\right)$ of water into $\mathrm{PET}$ fabrics.

instead of $K$, the area at the time $1 \mathrm{~min}, A_{1}$, was adopted as a measure of the wettability of fabric on assuming that the grafting would not affect other parameters in Eq. (1) and (4). Fig. 4 shows that $A_{1}$ increases with increasing the degree of grafting except for the grafting degree $3 \%$. This means that the advancing contact angle of water decreases and the hydrophilicity of PET fiber sur. face increases with the introduction of $\mathrm{COOH}$ onto the fiber surface.

Furthermore, the effects of grafting on the values of

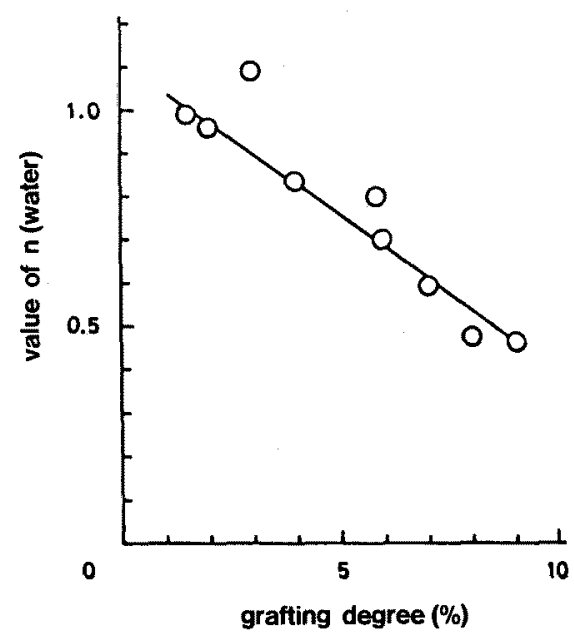

Fig. 5 Effect of grafting of acrylic acid on the capillary spreading of water (the value of $n$ ) into PET fabrics.

the exponent $n$ in Eq. (1), the slope of spreading during phase II shown in Fig. 3, were investigated. The results are shown in Fig. 5 as a function of grafting degree. The values of $n$ fairly decreased along the grafting degree also except for the case of $3 \%$. This decrease in $n$ might also be attributed to the decrease in the advancing con tact angle of fiber to water.

\subsection{FT-IR Characterization of Grafted Fabric}

As mentioned above, the values of $A_{1}$ and $n$ are correlated to the hydrophilicity of the surface, which should 
be in the intimate correlation with the amount of $\mathrm{COOH}$ on the surface. In this work, we applied the FT-IR measurements on grafted polyester fabrics by ATR technique using the $\mathrm{Ge}$ crystal to obtain the information about the amount of $\mathrm{COOH}$ on the surface. Fig. 6 shows the examples.

In the normal spectra, (b), there seemed no significant change due to the grafting. However, in the subtract spectra, (c), (grafted PET-original), a new absorption attributed to grafted $\mathrm{COOH}$ groups is observed clearly at $1695 \mathrm{~cm}^{-1}$. This absorption increased almost linearly against the grafting degree including $3 \%$.

However, one must keep the fact in mind that the ATR technique detects all the functional groups in a range of $\sim 4000 \AA$ from the surface. Therefore, such increase in $\mathrm{COOH}$ absorption is due to the introduction of $\mathrm{COOH}$ groups not only onto the fiber surface but also into the bulk region.

According to Ohguchi et $a l^{9)}$, who treated the grafted PET fabrics with $0.2 \%$ aqueous $\mathrm{Na}_{2} \mathrm{CO}_{3}$ at $80^{\circ} \mathrm{C}$ for 30 min, about $30 \%$ of $\mathrm{COOH}$ groups were transformed to their Na salt. Further, Holmes-Farley et al. ${ }^{10)}$ reported

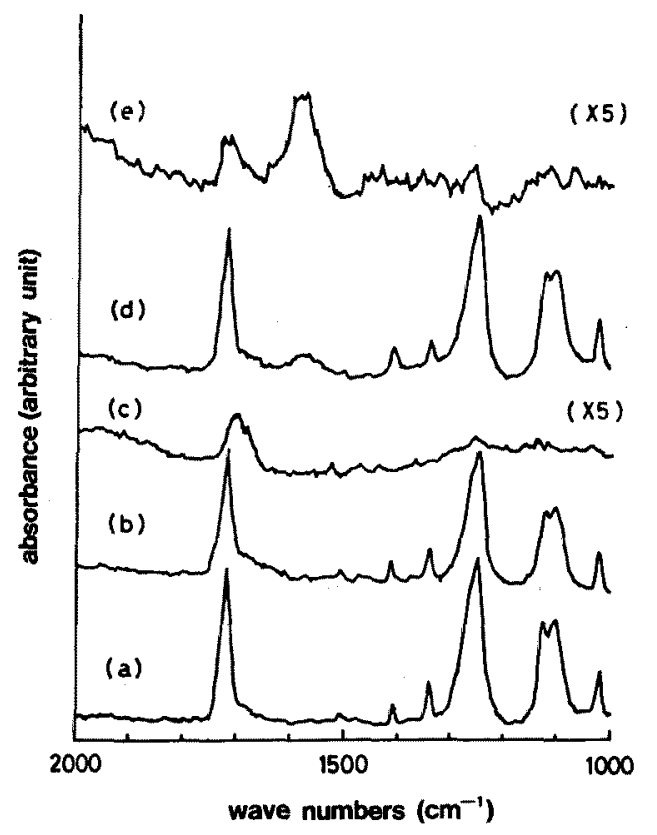

Fig. 6 FT-IR (ATR) spectra of grafted PET fabrics: grafting degree, $8 \%$. (a), original (ungrafted);

(b), grafted (acid form); (c), subtract [(b)-(a)];

(d), grafted (Na salt form), and (e), subtract [(d) $-(\mathrm{a})]$. on chromic acid treated polyethylene that the $\mathrm{COOH}$ groups could be classified into two subsets by examining chemical reactivities: those close enough to the surface to influence the wettability by water and those too deep to do so.

Then, we hypothesized that alkaline hydrolysis under mild condition would be able to transform only the $\mathrm{COOH}$ groups quite near the surface to their $\mathrm{Na}$ salt. And we analysed the surface of grafted fabrics after treated by $0.2 \%$ aqueous $\mathrm{Na}_{2} \mathrm{CO}_{3}$ solution at $25^{\circ} \mathrm{C}$ for $10 \mathrm{~min}$. As shown in Fig. 6, (d) and (e), an absorption attributed to COONa appears at $\sim 1580 \mathrm{~cm}^{-1}$ together with the absorption of $\mathrm{COOH}$ at $1695 \mathrm{~cm}^{-1}$. Consequently, it is reasonable that the transformation of $\mathrm{COOH}$ to $\mathrm{COONa}$ would afford the informations having higher degrees of surface sensitivity, that is, the region very close to the surface.

On the other hand, as seen in the subtract spectra, (c) and (d), the absorption at $1246 \mathrm{~cm}^{-1}$ attributed to the stretching of the $\mathrm{C}-\mathrm{O}$ single bond of $\mathrm{COOR}$ (ester) was unaffected even when grafted and/or treated with aqueous $\mathrm{Na}_{2} \mathrm{CO}_{3}$. Here, we newly defined the surface grafting degree, $S G D$, as a measure of the amount of $\mathrm{COOH}$ groups on fiber surface,

$$
S G D=S_{A}{ }^{g} / S_{B}{ }^{g}-S_{A}{ }^{\circ} / S_{B}{ }^{0}
$$

where $S_{A}$ is the area of COONa absorption at $1580 \mathrm{~cm}^{-1}$, $S_{B}$ the area at $1246 \mathrm{~cm}^{-1}$, and the superscripts, $g$ and $o$, refer to grafted and original fabrics, respectively.

The values of SGD were plotted against the grafting degree in Fig. 7. The value of $S G D$ increased along the grafting degree except for the case of $3 \%$. This result would mean that the grafting degree of fabiric by weight does not always represent the amount of $\mathrm{COOH}$ groups on the fiber surface.

\subsection{Soil Release Properties of Grafted Fabric}

The work of detergency $(\Delta E)$, the work per unit area required for complete displacement of oil by detergent, is defined by using free energies as

$$
\Delta E=\gamma_{O D}+\gamma_{D F}-\gamma_{O F}
$$

where $\gamma_{O D}, \gamma_{D F}$, and $\gamma_{O F}$ refer to the interfacial ten. sions (free energies) of oil/detergent, detergent/fiber, and oil/fiber interface, respectively.

Now, we consider the grafted fabric, $F^{\prime}$, and in this case the work of detergency is $\Delta E^{\prime}$,

$$
\Delta E^{\prime}=\gamma_{O D}+\gamma_{D F^{\prime}}-\gamma_{O F^{\prime}}
$$

The effects of grafting on detergency would be evalu. 


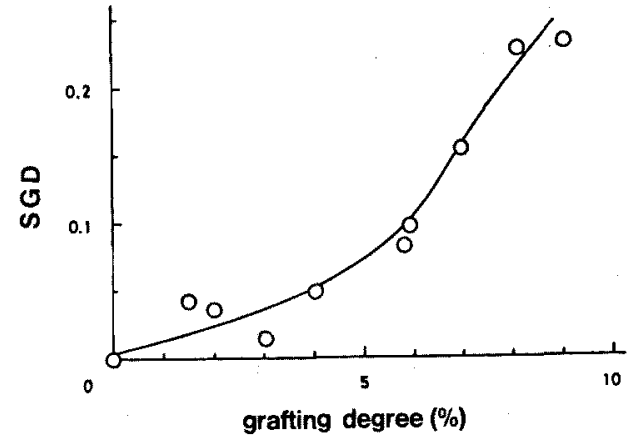

Fig. 7 Relation between the surface grafting degree $(S G D)$ and the grafting degree.

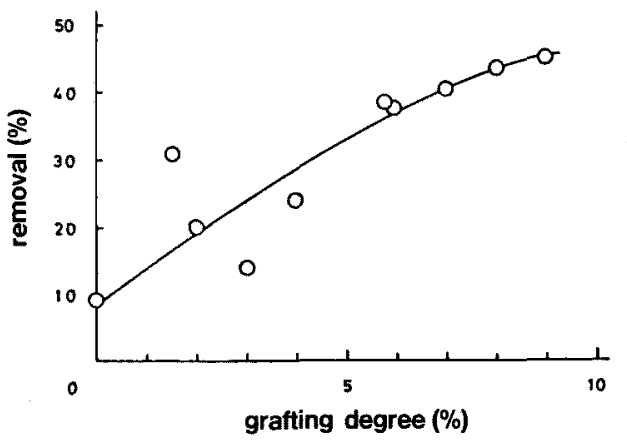

Fig. 8 Effect of grafting of acrylic acid on the removal of squalane from PET fabrics.

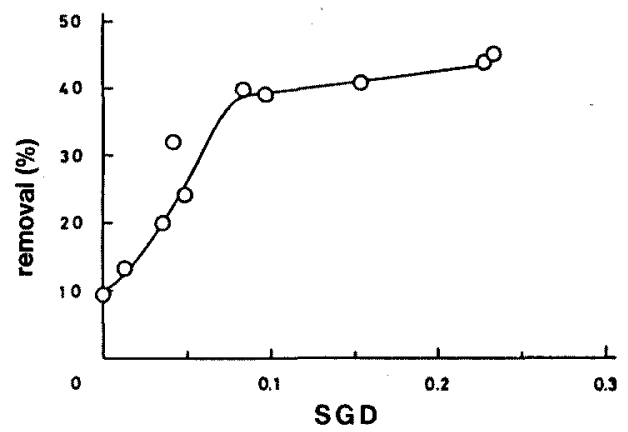

Fig. 9 Relation between the surface grafting degree $(S G D)$ and the removal of squalane.

ated by the difference of these two works, $\Delta \Delta E$,

$$
\Delta \Delta E=\Delta E^{\prime}-\Delta E=\gamma_{D F}-\gamma_{O F}-\gamma_{D F}+\gamma_{O F}
$$

Here, the extend Fowkes equation ${ }^{11)}$ is applied to Eq. (8), and $\triangle \Delta E$ is transformed to

$$
\begin{aligned}
\Delta \Delta E= & 2\left(\sqrt{\gamma_{D}^{d}}-\sqrt{\gamma_{O}^{d}}\right)\left(\sqrt{\gamma_{F}^{d}}-\sqrt{\gamma_{F}^{d \sigma}}\right)+ \\
& 2\left(\sqrt{\gamma_{b}^{p}}-\sqrt{\gamma_{O}^{b}}\right)\left(\sqrt{\gamma_{F}^{b}}-\sqrt{\gamma_{F}^{\phi \beta}}\right)
\end{aligned}
$$

where $\gamma_{t}, \gamma_{O}$, and $\gamma_{F}$ are the surface free energies of detergent solution, oil, and fibers, respectively, and the superscripts, $d$ and $p$, refer to the dispersive and polar components of them.

According to Sumiya et al. ${ }^{12)}$, who treated the PET film with aqueous $\mathrm{NaOH}$, the dispersive component of surface free energy $\left(\gamma_{F}^{d}\right)$ of PET were kept constant $(29-30 \mathrm{dyne} / \mathrm{cm})$, while the polar one $\left(\gamma_{F} p\right)$ increased along the treating time. As the $\mathrm{NaOH}$ treatment also in troduces the COOH groups on the PET surface, it may be reasonable to expect that the grafted PET has the similar constant dispersive component $(\sim 30$ dyne $/ \mathrm{cm})$; that is $\gamma_{F}{ }^{d}=\gamma_{F}{ }^{d}$, and the polar component increases with the grafting degree $\left(\gamma_{F}^{p}<\gamma_{F}{ }^{p}\right)$. Then, the first term of Eq. (9) would be zero, and as the soil is nonpolar $\left(\gamma_{0}^{p}\right.$ $=0$ ), Eq. (9) is simplified as

$$
\Delta \Delta E=2 \sqrt{\gamma_{D}^{p}}\left(\sqrt{\gamma_{F}^{p}}-\sqrt{\gamma_{F}{ }^{p}}\right)
$$

As $\gamma_{F}{ }^{p p}$ is larger than $\gamma_{F}^{p}, \Delta \Delta E$ must be negative Therefore, the removal of oily soil from the grafted PET should be improved by grafting.

In washing experiment, the fabric specimens were the same used in the spreading studies. As shown in Fig. 8 , the removal of squalane was improved in all fabrics com. pared to that of ungrafted one. But, during low grafting degrees there appeared a somewhat complicated result, which was quite similar to Fig. 7.

Then, we studied the relations between $S G D$ and the removal because these are regarded to be deeply corre. lated. As shown in Fig. 9, there observed a smooth rela. tion without any peculiarities. This observation and the fact that the removal of oily soil is deeply dependent on the surface free energies of fiber would indicate that $S G D$ values can be employed as an alternative to the sur. face free energy. Further, as easily suspected, there also existed the relations between the removal and the values of $A_{1}$ and $n$.

\subsection{Interpretation of Peculiarities of the Case of Graft- ing Degree of 3\%}

In this work, for the case of grafting degree of $3 \%$, there observed peculiarities in $A_{I}, n, S G D$, and removal.

One might think that such peculiarities should be due to the experimental error in determination of grafting degree and the actual grafting degree would be less than $3 \%$. Truely, the water regain, which has been said to correlate to the amount of introduced $\mathrm{COOH}$ of $3 \%$ grafted fabric was smaller than that of $2 \%$.

But, the $\mathrm{COOH}$ on the surface would be more effective 
on the water regain than that in the bulk and the absorption at $1695 \mathrm{~cm}^{-1}$ due to $\mathrm{COOH}$ increased almost linearly against the grafting degree including $3 \%$. As the $\mathrm{COOH}$ absorption would deeply correlate to the amount of total introduced $\mathrm{COOH}$, it is reasonably concluded that the grafting degree should be actually $3 \%$ on weight but some incidental deviation in gafting conditions (probably the rate of increasing temperature) would result in those peculiarities.

$A_{1}, n, S G D$ and removal where the large deviations appeared are all surface-depending properties. And, Ohguchi ${ }^{7)}$ reported that the grafting in this condition occurs at the whole region of fibers. Consequently, these peculiarities of the case of grafting degree of $3 \%$ would be explained as follows: The grafting degree may represent the amount of $\mathrm{COOH}$ groups of whole fabrics including the bulk but not that on the fiber surface. Namely, the value of $3 \%$ is the total amount of $\mathrm{COOH}$ and grafting would remarkably proceed in the bulk region, but the degree of surface grafting would be smaller than ex. pected.

However, it should be emphasized that those peculiarities are quite incidental and would not appear if the grafting is carried out under more controlled conditions.

\section{CONCLUSION}

The effects of grafting with acrylic acid on the wetta. bility of polyester fabric have been made clear by study. ing capillary spreading of water in fabrics and soil release properties. The grafting of acrylic acid made fiber surfaces more hydrophilic and decreased the contact angle of the fiber to water and resulted in the increase of $K\left(A_{1}\right)$ and decrease of the exponent $n$, and the soil release properties were improved. Consequently, by using FT-IR spectroscopy, the relations among the values of $A_{1}$ and $n$, the improvement in soil release property, and the surface grafting degree $(S G D)$ were made clear.

\section{REFERENCES}

1) T. Kawase, T. Fujii, and M. Minagawa, Text. Res. J., 57. 686 (1987)

2) T. Kawase, S. Sekoguchi, T. Fujii, and M. Minagawa, Text. Res. J., 56, 409 (1986)

3 ) T. Kawase, S. Sekoguchi, T. Fujii, and M. Minagawa, Text. Res. J., 56, 617 (1986)

4) T. Kawase, Y. Morimoto, T. Fujii, and M. Minagawa, Text. Res. J., 58, 306 (1988)

5) T. Gillespie, J. Coll. Sci., 13, 32 (1958)

6) E. Kissa, J. Colloid. Interfac. Sci., 83, 265 (1981)

7) M. Ohguchi, K. Igeta, and T. Yasumura, Sen-i Gakkaishi, 36, T435 (1980)

8) E. Kissa and R. Dettre, Text, Res. J., 45, 773 (1975)

9 ) M. Ohguchi and T. Yasumura, Sen-i Gakkaishi, 37 T354 (1981)

10) S. R. Holmes-Farley and G. M. Whitesides, Langmuir, 3. 62 (1987)

11) D. K. Owens and R. C. Wendt, I. Appl. Polym. Sci., 13, 1741 (1969)

12) K. Sumiya, T. Taii, K. Nakamae, and T. Matsumoto, J. Adhesion Soc. Japan, 345 (1982)

\section{ポリエステル織物のぬれと SR 性に及ぼす アクリル酸グラフト重合の影響}

\section{大阪市立大学生活科学部川瀨德三，森本欣子，藤井富美子，皆川 基}

アクリル酸のグラフト重合により表面改質したポリエ ステル織物の水に対する好挙動の変化を，(1)織物中で の水の毛管ぬれ広がりの測定，(2)無極性油よごれを用い ての洗浄実験および(3) FT-IRを用いた表面キャラクタ リゼーションにより総合的に調べた。

毛管ぬれ測定の結果，一般に，1分後のぬれ広がり面 積 $A_{1}$ はダラフトの進行に伴い增大し，反対に水のぬれ 広がり速度の尺度 $n$ は滅少した。グラフト化に伴い油 よごれの洗净性も一般に向上した。しかし，グラフト率
はバルク（内部）も含むため，表面の親水化尺度として 単純にグラフト染を採用すると極小が認妨的るなど複 雑な関係を与えた。

表面に導入された $\mathrm{COOH}$ 基とバルクのそれとを区別 するため，温和な条件で中和することにより表面の $\mathrm{COOH}$ 基のみを $\mathrm{Na}$ 㙉に変換 L, FT - IRにより $1580 \mathrm{~cm}^{-1}$ と $1246 \mathrm{~cm}^{-1}$ のピークの面積比を求め，表面グラフト尺 度（SGD）を算出した。SGD はグラフトによる表面親 水化の影響を定量的に説明した。 